\title{
Aplikasi Analisis (Path Analysis) Berdasarkan Urutan Penempatan Variabel dalam Penelitian
}

\author{
Sudaryono \\ STMIK Raharja Tangerang, Email: Sudaryono1@yahoo.co.id
}

\begin{abstract}
Abstrak: Dalam suatu penelitian kuantitatif, suatu metode yang mengkaji urutan sebab akibat antara sejumlah variabel dalam suatu model penelitian disebut metode path analysis (analisis jalur). Dikarenakan pemikiran sebab akibat memainkan peranan atau aturan yang sangat penting di mana path analysis tersebut diaplikasikan, maka dengan menampilkan unsur-unsur path analysis dengan menerapkan analisis korelasi di antara sesama variabel berdasarkan urutan pengaruhnya, akan memberikan gambaran betapa pentingnya analisis jalur ini untuk diketahui oleh peneliti. Tujuan analisis jalur adalah menerangkan akibat langsung dan tidak langsung seperangkat variabel, sebagai variabel penyebab, terhadap variabel lainnya yang merupakan variabel akibat. Selain itu tujuan penulisan ini adalah untuk menambah khasanah model-model penelitian yang dapat digunakan untuk menganalisis pola hubungan antar variabel. Rumusan masalah dalam tulisan memusatkan perhatian apakah analisis jalur sangat efektif digunakan dalam penelitian pendidikan dan menjawab pertanyaan permasalahan penelitian dengan baik. Hasil penelusuran literatur dan contoh-contoh penelitian yang menggunakan analisis jalur menunjukkan bahwa analisis jalur sangat efektif dan perlu dikembangkan dalam penelitian pendidikan.
\end{abstract}

Kata kunci: Penelitian kuantitatif, Aplikasi Path Analysis,Analisis Korelasi, Akibat Langsung, Akibat Tidak Langsung.

\begin{abstract}
In quantitative research there is a method called path analysis that examines chronological cause and effect among variables. Since cause and effect play an important role guideline in which the analysis is applied, showing the path analysis components with applied corelation analysis among variables based on their chronological effect would give description how important the path analysis is to be acknowledged by reserachers. It's objective is to examine direct and indirect effect a set of variables, as the cause variables towards other variables as the effect variables. The purpose this article is to enrich research methods that may be used to analysis the relation patern among the variables. Problem formulation of this article focuses on the question is path analysis effective for educational research and can it answer issues in educational research. Literature reviews and researchs using path analysis reveal that it is very effective and needs to be developed in educational research.
\end{abstract}

Keywords: Research Quantitative, Path Analysis Applied, Correlation Analysis, Direct Effect, Indirect Effect.

\section{Pendahuluan}

Penelitian adalah suatu cara ilmiah untuk memecahkan suatu masalah dan untuk menembus batas-batas ketidaktahuan manusia. Kegiatan penelitian dengan mengumpulkan dan memproses fakta-fakta yang ada sehingga fakta tersebut dapat dikomunikasikan oleh peneliti dan hasilhasilnya dapat dinikmati serta digunakan untuk kepentingan manusia. Pada umumnya analisis penelitian dalam penelitian pendidikan dihadapkan kepada masalah yang berfaktor ganda. Masalahmasalah dalam pendidikan dapat dikatakan tidak mungkin dijelaskan dengan hanya menggunakan model analisis bivariat, yang hanya menggunakan faktor tunggal saja. Lagi pula masalah yang bersifat sangat pribadi, seperti prestasi siswa, status ekonomi orang tua siswa dan faktor-faktor lain, ternyata dipengaruhi oleh banyak hal yang saling berkaitan dengan faktor lainnya sehingga bersifat serba ganda (Asmin, 2002).

Misalnya prestasi siswa ternyata dipengaruhi oleh potensi anak, dan potensi ini dipengaruhi pula oleh tingkat IQ anak, dan IQ dipengaruhi pula oleh status ekonomi, demikian seterusnya kalau 
ditelusuri lagi ekonomi masih dipengaruhi oleh faktor lain. Oleh karena itu, para peneliti pendidikan dan peneliti sosial menjadi terbiasa dengan metode yang dikenal dengan sebutan analisis multivariat. Analisis multivariat adalah teknik statistik yang memfokuskan dan membuat jelas struktur hubungan yang serentak di antara tiga atau lebih variabel atau fenomena (Sularso, 2003). Dalam melakukan analisis multivariat, peneliti sering disibukkan dengan adanya beberapa kemungkinan yang dapat terjadi pada hubungan antar berbagai variabel, seperti (1) apakah hubungan tersebut memang ada, (2) apakah hubungan-hubungan tersebut memang wajar, dan (3) apakah hubungan-hubungan itu menunjukkan adanya arah dan urutan?

Timbul pertanyaan terutama bilamana hubungan yang nampaknya nyata kemudian terbukti hanya bersifat semu, berkala, karena variabel-variabel yang berhubungan itu masingmasing dipengaruhi oleh variabel lain yang tidak termasuk dalam kerangka analisis? Contoh: hubungan antara gaya berpakaian dengan konsumsi makanan. Kita sering melihat banyak orang muda terutama gadis-gadis bercelana pendek jalan-jalan sambil makan es krim. Apakah hubungan nyata antara gaya berpakaian "celana pendek" dengan konsumsi makanan "es krim"? Kalau diperhatikan kondisi lingkungan, kemudian ternyata hubungan antara keduanya timbul karena adanya variabel lain yang terlupakan, yakni, "udara (musim) panas". Udara panas mendorong orang jalan-jalan bercelana pendek untuk mengurangi rasa pengap dan membuat orang merasa ingin minum yang diinginkan.

Pertanyaan kedua mempertanyakan kewajaran hubungan. Perhatikan contoh tentang hubungan antara pendidikan dan pangkat seseorang. Pendidikan umumnya berkaitan dengan kemampuan dan keterampilan. Wajarlah bila orang yang berpendidikan tinggi menduduki jabatan tinggi, sedangkan berpendidikan rendah menduduki jabatan rendah. Ternyata kalau diperhatikan lebih lanjut, jabatan tinggi selain berpendidikan tinggi juga memiliki pengalaman kerja. Dengan demikian hubungan antara pendidikan dan pangkat jabatan dapat berubah bertambah besar atau berkurang karena faktor pengalaman.

Pertanyaan ketiga menyangkut arah dan urutan.
Perhatikan contoh tentang hubungan antara derajat sosial ayah dan jabatan anaknya. Dapatkah di jaman sekarang ini mengikuti pola pikir lama bahwa anak wajib menjunjung derajat orang tua, ataukah sebaliknya? Mengikuti teori sosialisasi dan pengaruh lingkungan, apakah derajat orang tua, terutama derajat sosial ayah, mempengaruhi cita-cita dan derajat yang hendak dicapai anak-anaknya?

Kesulitan-kesulitan macam ini mendorong para peneliti pendidikan maupun peneliti sosial untuk mencari jalan atau metode baru untuk membuat analisis secara lebih tepat. Salah satu metode baru dalam analisis multivariate yang dianggap effisien dan efektif untuk mengatasi berbagai masalah hubungan adalah path analysis, yang diterjemahkan menjadi analisis jalur. Berdasarkan uraian di atas, tulisan ini memusat-kan perhatian: apakah analisis jalur (path analysis) sangat efektif digunakan dalam penelitian pendidikan dan menjawab pertanyaan permasa-lahan penelitian dengan baik. Tujuan penulisan ini adalah untuk menerangkan akibat langsung dan tidak langsung seperangkat variabel, sebagai variabel penyebab, terhadap variabel lainnya yang merupakan variabel akibat yang disebut analisis jalur. Selain itu, untuk menambah khasanah model-model penelitian yang dapat digunakan untuk menganalisis pola hubungan antar variabel terutama dalam bidang pendidikan.

\section{Kajian Literatur dan Pembahasan Pengertian Path Analysis}

Teknik analisis jalur pertama kali dikembangkan oleh Sewell Wright pada tahun 1930-an. Teknik ini digunakan untuk menguji hubungan kausal yang diduga masuk akal (plausibility) antara satu variabel dengan variabel lain di dalam kondisi noneksperimental (Muhidin, 2009). Metode path analysis adalah suatu metode yang mengkaji pengaruh (efek) langsung maupun tidak langsung dari variabel-variabel yang dihipotesiskan sebagai akibat pengaruh perlakuan terhadap variabel tersebut. Path analysis ini bukanlah suatu metode penemuan sebab akibat, akan tetapi suatu metode yang diterapkan untuk suatu causal model yang diformulasikan oleh peneliti pada pengetahuan dasar dan teoritis yang dikembangkan.

Kerlinger (2003) mengatakan bahwa yang dimaksud dengan analisis jalur (path analysis) adalah suatu bentuk terapan dari analisis multiregresi. Dalam 
hal ini digunakan diagram jalur yang kompleks. Dengan menggunakannya dapat dihitung besarnya pengaruh langsung dari variabel-variabel bebas terhadap suatu variabel terikat. Pengaruh-pengaruh itu tercermin dalam apa yang disebut sebagai koefisien jalur (path coefisients) yang sesungguhnya merupakan koefisien regresi yang telah dibakukan (yakni $\mathbf{\beta}$ ). Meskipun analisis jalur ini sampai sekarang telah dan tetap merupakan metode analitis dan heuristik (rasa ingin tahu) yang penting, diragukan apakah ia akan terus digunakan untuk membantu pengujian model guna mengetahui kongruensi dengan data yang diperoleh.

Menurut Pedhazur (1982), analisis jalur telah dikembangkan oleh Sewall Wright sebagai suatu metode untuk mengkaji efek langsung atau efek tidak langsung dari variabel-variabel yang dihipotesiskan sebagai penyebab efek-efek variabel yang diperlukan dalam penelitian. Hal yang perlu dipahami adalah bahwa sebenarnya analisis jalur bukanlah suatu metode yang digunakan untuk menemukan penyebabpenyebab, akan tetapi digunakan untuk menemukan penjelasan tentang pola-pola hubungan langsung dan tidak langsung dari suatu model kausal yang disusun berdasarkan pertimbangan-pertimbangan teoritis dan pengetahuan peneliti.

Jadi secara umum prosedur analisis jalur dapat diformulasikan sebagai sebuah estimasi koefisien dari seperangkat persamaan struktural linear yang menggambarkan hubungan sebab akibat (cause and effect relationships) yang dihipotesiskan oleh peneliti. Meskipun tidak esensial dalam analisis numerical, tetapi sangat berguna jika pola-pola hubungan kausal antar variabel ditampilkan dalam bentuk gambar, yang dikenal dengan diagram jalur (path diagram). Kegunaan diagram jalur untuk membantu menkonseptualisasikan masalah atau menguji hipotesis yang kompleks, dan juga untuk mengenali implikasi empirik dari teori yang sedang diuji (Winarsunu, 2003).

Tujuan utama path analysis adalah ....a method of measurement the direct influence along each separate path in such a system and thus of finding the degree to which variation of a given effect is determined by each particular cause. The of method depend on the combination of knowledge of the degree of correlation among the variables in a system with such knowledge as may possessed of the causal relations (Maruyama, 1998). Dalam diagram jalur dapat dilihat adanya akibat langsung dan tidak langsung dari suatu variabel ke variabel lain. Jika di antara dua variabel terdapat hubungan kausal maka harus ditentukan terlebih dahulu arah hubungan tersebut. Penentuan arah hubungan kausal ini dibuat atas dasar teori dan pengetahuan yang telah ada. Hubungan kausal antara dua variabel yang hanya memiliki satu arah atau unidireksional disebut sebagai model yang memiliki hubungan yang recursive, dan apabila memiliki dua arah disebut nonrecursive. Dalam penelitian eksperimen, peneliti tertarik kepada cara memanipulasi variabel dan cara mengobservasi di dalam mana manipulasi dilakukan terhadap efek variasi variabel terikat (dependent variabel).

Dalam hal ini untuk meyakinkan bahwa variasi variabel yang diobservasi yang ada dalam variabel terikat adalah benar-benar dapat dimanipulasi, penelitian harus dapat pula mengontrol variabelvariabel relevan lainnya. Satu dari metode yang paling memiliki kekuatan untuk pengontrolan tersebut adalah randominasi. Dalam hal manipulasi dan randominasi, peneliti harus merasa memiliki alasan kepercayaan yang kuat dalam menetapkan jenis-jenis perlakuan yang dibutuhkan dalam upaya menghasilkan perubahan-perubahan (variasi) dalam variabel terikat. Situasi seperti ini akan memiliki pertimbangan yang lebih mendua arti bila dilakukan dalam penelitian noneksperimental, karena peneliti tidak dapat memanipulasi atau melakukan randominasi. Selama memungkinkan untuk menggunakan pengontrolan statistik sebagai pengganti randomisasi, peneliti harus secara tetap siap siaga untuk menghadapi kesukaran yang tersembunyi yang menjadi sifat interpretasi dalam analisis data dari penelitian non eksperimen tersebut. Hal ini mungkin merupakan peringatan yang sering disampaikan dalam proses penelitian.

Korelasi bukanlah suatu bukti kuat yang dapat digunakan untuk menjelaskan sebab akibat. Demikian juga tidak ada indeks lain yang secara mutlak dapat digunakan untuk menjelaskan adanya sebab akibat, tanpa memperhatikan apakah indeks tersebut diperoleh dari data penelitian eksperimen 
atau penelitian non-eksperimen. Menurut Pedhazur (1982), kovarian atau korelasi antara variabelvariabel mungkin dapat digunakan untuk menjelaskan suatu sebab akibat. Menurutnya, suatu skema penjelasan kurang cocok digunakan untuk menjelaskan data, akan tetapi lebih sesuai digunakan untuk hal yang bersifat pengetahuan, formulasi teoritis, dan asumsi-asumsi serta analisis logika. Skema penjelasan ini berguna bagi peneliti untuk memperlihatkan tipe analisis yang diterapkan pada data, dan tidak ada cara yang lain.

Suatu kelengkapan yang terdapat dalam analisis ini adalah bahwa posisi seorang peneliti dapat menetapkan apakah data tersebut konsisten dengan skema penjelasan (eksplanatory scheme) atau tidak. Jika data tidak konsisten dengan exsplanatory model, maka keraguan akan mewarnai teori yang digunakan dalam penelitian itu. Namun demikian kekonsistenan data dengan eksplonatory model, bukanlah suatu bukti kuat terhadap suatu teori ini hanyalah berupa petunjuk jalan ke arah itu. Dalam hal ini, mungkin data yang digunakan konsisten dengan model-model kausal yang digunakan. Sebagaimana yang biasa terdapat pada model, bahwa suatu pertimbangan sangat dibutuhkan. Misalnya mempertimbangkan model-model yang melibatkan tiga variabel berikut.
(1) $\mathrm{X} \rightarrow \mathrm{Y} \rightarrow \mathrm{Z}$
(2) $\mathrm{Y} \rightarrow \mathrm{X} \rightarrow \mathrm{Z}$

Model pertama menyatakan bahwa $X$ mempengaruhi $Y$. sebaliknya $Y$ mempengaruhi $Z$. Model kedua menyatakan bahwa $Y$ mempengaruhi $X$, sehingga $X$ mempengaruhi $Z$. Korelasi-korelasi antara tiga variabel yang diobservasi mungkin konsisten dengan kedua model, dan ini memungkinkan bahwa $X$ mendahului $Y$ dalam urutan waktu. Bila hal ini merupakan kasus peneliti dapat menolak model (2) dalam model itu. Kemudian perlu ditetapkan metode analisis yang digunakan untuk membuat perumusan model teoritis yang dapat dipertahankan oleh peneliti. Salah satu dari metode itu adalah path analisis. Kajian berikut bukanlah dimaksudkan untuk melemahkan analisis lainnya, tetapi sebaliknya untuk memperkenalkan kepada pembaca beberapa prinsip dasar dan penerapan path analysis dalam penelitian pendidikan dan penelitian sosial lainnya.

Menurut penulis, secara sistemik path analysis mengikuti pola model struktural, sehingga langkah awal untuk mengerjakan atau penerapan model path analysis adalah merumuskan persamaan struktural dan diagram jalur yang berdasarkan kajian teori dalam bidang pendidikan. Informasi diberikan apabila tujuan penelitian ingin mendapatkan model untuk kepentingan prediksi, maka yang tepat digunakan adalah model struktural. Model ini mirip dengan path analysis, yang membedakan adalah: kalau di dalam path analysis data yang dianalisis adalah data baku, sedangkan di dalam model struktural menggu-nakan data mentah. Dengan demikian hasil analisis model struktural kurang tepat jika disajikan dalam bentuk diagram path dan lebih cocok disajikan dalam sistem persamaan.

\section{Variabel Eksogen dan Endogen}

Secara teoretis variabel dapat didefinisikan sebagai atribut seseorang atau objek, yang mempunyai variasi antara satu orang dengan yang lain atau satu objek dengan objek yang lain (Sugiyono, 2006). Variabel juga dapat merupakan atribut dari bidang keilmuan atau kegiatan tertentu. Dalam model kausal, harus dibedakan antara variabel eksogen dan endogen. Variabel eksogen adalah variabel yang variabilitasnya diasumsikan ditentukan oleh sebab-sebab yang berada di luar model. Sedangkan variabel endogen adalah variabel yang variasinya dapat diterangkan oleh variabel eksogen dan endogen yang berada di dalam sistem. Variabel endogen diperlakukan sebagai variabel terikat dalam suatu himpunan variabel tertentu mungkin juga dikonsepsikan sebagai variabel bebas dalam hubungannya dengan variabel yang lain. Ditambahkan oleh Hasan (2002) bahwa di samping ada variabel eksogen dan endogen masih ada satu variabel lagi yaitu variabel kesalahan. Variabel eksogen adalah setiap variabel yang mempengaruhi variabel lain dan variabel endogen adalah setiap variabel yang mendapat pengaruh dari variabel lain. Sedangkan variabel kesalahan adalah semua faktor lain yang mempengaruhi variabel endogen, dan dapat dipandang sebagai gabungan semua variabel eksogen yang tidak diukur plus kesalahan pengukuran.

Jarang sekali ada usaha yang dilakukan untuk menjelaskan variability suatu variabel eksogen atau perbedaan itu hanya merupakan hubungan- 
hubungan antara variabel eksogen lain. Di sisi lain, variabel endogen adalah suatu variasi yang dijelaskan oleh variabel eksogen atau endogen yang terdapat dalam sistem tersebut. Perbedaan antara kedua jenis variabel ini dilukiskan pada Gambar 1.

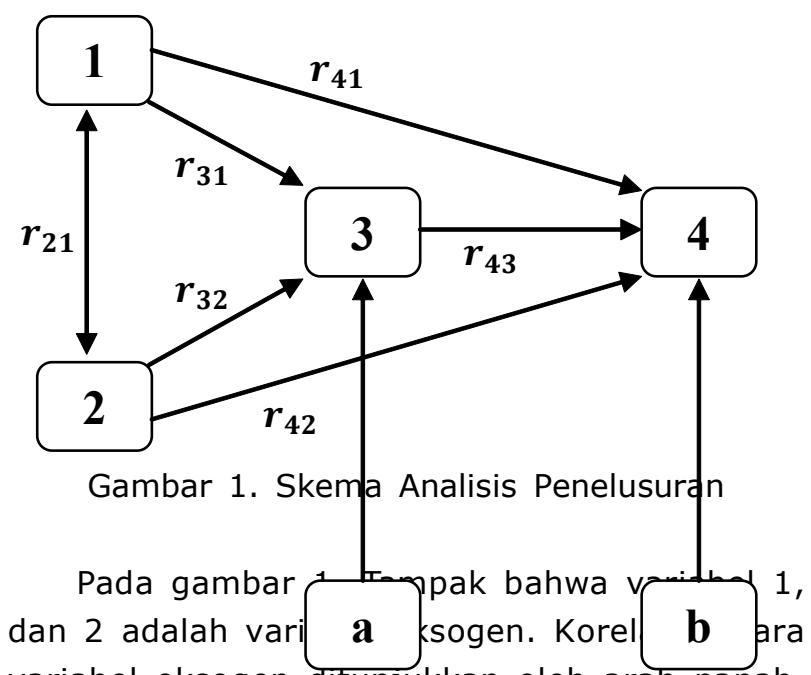
variabel eksogen ditunjukkan oleh arah panah, di mana peneliti tida $\mathbf{P}_{\boldsymbol{k}} \boldsymbol{a}$ perlu mengurutk $\mathbf{P}_{\boldsymbol{\beta}} \boldsymbol{b}$ satu variabel menjadi penyebab yang lain. Konsekwensinya, hubungan antara residual sesama variabel eksogen $\left(r_{12}\right)$ tidak dianalisis dalam sistem itu.

Variabel 3, dan 4 adalah variabel endogen. Di sini terjadi hubungan langsung. Bentuk hubungan tidak langsung dilukiskan dari variabelvariabel yang diambil sebagai penyebab (variabel bebas) kepada variabel yang diambil sebagai akibat (variabel terikat). Dua lintasan ini terlihat dari variabel 1 , dan 2 ke 3 yang menyatakan bahwa variabel 3 adalah dependen 1 dan 2 . Berarti bahwa pada suatu saat sebuah variabel tidak dapat sekaligus menjadi penyebab dan sebagai akibat dari variabel lainnya.

Misalnya, jika variabel 2 diambil sebagai penyebab variabel 3 , maka kemungkinan variabel 3 menjadi penyebab variabel 2 adalah mustahil. Variabel endogen diperlakukan sebagai variabel terikat dalam sekelompok variabel yang juga disusun sebagai variabel bebas di dalam hubungan variabel-variabel lainnya. Misalnya, variabel 3 diambil sebagai variabel terikat variabel 1 , dan 2 , dan juga sebagai variabel bebas pada variabel 4 . Ini merupakan contoh hubungan kausal tak langsung. Karena hampir tidak mungkin menghitung total varians sebuah variabel, residu variabel dikenalkan untuk menyatakan efek dari variabel-variabel yang dilibatkan dalam model tersebut. Pada Gambar 1 tampak pula a, dan b merupakan residu-residu variabel, di mana diasumsikan bahwa residu-residu itu tidak berkorelasi sesamanya ataupun dengan variabel pendahulu yang ada dalam model. Misalnya, a tidak berkorelasi dengan $b$ dan juga tidak berkorelasi dengan variabel 1 dan 2. Sedangkan manfaat-manfaat dari path analysis adalah untuk (Riduwan, 2007):

1. Penjelasan (explanation) terhadap fenomena yang dipelajari atau masalah yang diteliti.

2. Prediksi nilai variabel terikat $(Y)$ berdasarkan nilai variabel bebas $(X)$, dan prediksi dengan path analysis ini bersifat kualitatif.

3. Faktor determinan yaitu ) penentuan variabel bebas $(X)$ mana yang berpengaruh dominan terhadap variabel terikat $(Y)$, juga dapat digunakan untuk menelusuri mekanisme (jalur-jalur) pengaruh variabel bebas (X) terhadap variabel terikat $(\mathrm{Y})$.

4. Pengujian model, menggunakan theory trimming, baik untuk uji reliabilitas (uji keajegan) konsep yang sudah ada ataupun uji pengembangan konsep baru.

Berdasarkan pada penjelasan di atas dapat dikatakan bahwa, keunggulan path analysis adalah adanya suatu usaha untuk melakukan dekomposisi terhadap korelasi antara variabel eksogen dengan endogen, di mana hal ini akan meningkatkan interpretasi terhadap pola-pola hubungan atau pengaruh dari satu variabel terhadap variabel yang lain.

\section{Asumsi-asumsi Path Analysis}

Seperti model-model analisis statistik parametrik lainnya, bahwa penerapan yang memadai dari sebuah prosedur statistik untuk kepentingan pengujian hipotesis bergantung pada seberapa jauh seperangkat asumsi yang mendasari prosedur itu memenuhi syarat untuk tujuan analisis tersebut. Model analisis jalur hanya sesuai untuk data yang memenuhi asumsi-asumsi yang 
berlaku bagi analisis regresi, antara lain (Abdurahman, 2011): Pertama, hubungan-hubungan antara variabel-variabel dalam model adalah linier, yaitu asumsi bahwa semua hubungan antar variabel yang ada dalam model adalah hubungan yang mengikuti garis lurus, bukan garis lengkung (curvilinear).

Kedua, residual-residual yang muncul tidak berkorelasi dengan variabel yang mendahuluinya dalam model dan juga tidak berkorelasi di antara sesama variabel itu sendiri. Implikasi dari asumsi ini adalah bahwa semua variabel-variabel yang relevan harus dilibatkan dalam sistem itu. Variabel endogen disusun sebagai kombinasi linier dari variabel-variabel eksogen atau endogen lain yang ada dalam sistem, dibarengi sebuah residu. Variabel eksogen diperlukan sebagai "pemberi". Jika variabel-variabel eksogen dikorelasikan sesamanya, korelasi tersebut diperlakukan sebagai "pemberi" dan sisanya tidak dianalisis.

Ketiga, asumsi normalitas sangat penting terutama untuk kepentingan penarikan kesimpulan. Pada beberapa variabel hasil observasi cenderung memiliki frekuensi yang posisinya berada di pusat atau ditengah distribusi. Distribusi normal merupakan hal yang penting dalam statistik yang digunakan sebagai rujukan untuk menentukan ukuran normalitas tidaknya suatu distribusi data sampel. Keempat, asumsi homogenitas yang sering juga disebut homoscedastisitas yaitu apabila skor-skor variabel endogen untuk setiap skor tertentu pada variabel eksogen selalu sama atau hampir sama (Goldstein, 1985).

Kelima, model analisis jalur cocok untuk variabel yang mempunyai skala interval atau rasio dan kurang cocok untuk variabel berskala nominal atau ordinal. Jika salah satu variabel dalam model yang dispesifikasikan mempunyai skala ordinal atau nominal, maka koefisien korelasi variabel tersebut harus dihitung dengan teknik statistik nonparametrik tertentu. Kemudian koefisien korelasi yang dihasilkan dimasukkan ke dalam matriks korelasi yang akan dipakai dalam analisis jalur.

\section{Path Coefficients}

Koefisien path merupakan pecahan untuk simpangan baku dari variabel terikat (dengan tanda yang sesuai) untuk ditandai dengan faktor yang langsung bertanggungjawab di mana pecahan itu dijumpai, jika variasi faktor untuk tingkat yang sama terdapat dalam data yang diobservasi. Selama yang lain-lain (mengandung residual faktorfaktor) adalah konstan. Dengan kata lain path koeffisien menyatakan efek langsung dari variabel yang diambil sebagai penyebab terhadap variabel yang diambil sebagai efek. Koefisien path menunjukkan besarnya pengaruh langsung suatu variabel terhadap variabel lain, bila pengaruhpengaruh lain yang berhubungan sudah diperhitungkan.

Koefisien path ini identik dengan koefisien regresi (beta), bila variabelnya diukur dalam bentuk standard. Cara memperoleh koefisien ini dapat dilakukan dengan dua cara, yaitu (Kusnendi, 2005): pertama, dengan langsung menggunakan data mentah dan menghitung koefisien parsial dari input data yang terstandard, dan kedua, dengan menggunakan metode zeroorder correlation antar semua variabel dan dengan matriks interkorelasi yang ada. Lambang yang digunakan untuk path koeffisien adalah " $p$ " dengan dua subscript (tulisan di bawah garis) yang pertama menyatakan efek (atau variabel terikat), dan subscript kedua menyatakan kausal/ penyebab (independent variable). Misalnya $\mathrm{p}_{32}$ menyatakan efek langsung dari variabel 2 pada variabel 3 .

\section{Ketergantungan Variabel-Variabel dalam Persamaan-Persamaan.}

Sebagai suatu teknik untuk mengaitkan hubungan antar variabel yang diteliti dengan asumsi bahwa terdapat beberapa variabel utama yang secara utuh menentukannya. Variabel-variabel utama tersebut mungkin diobservari melalui variabelvariabel itu sendiri (seperti tingkat pendapatan, sebagai suatu penentu dalam pembayaran pajak), atau mungkin didasarkan pada variabelvariabel yang lain seperti (tingkat inteligensi sebagai penentu skor-skor tes bervariasi yang sedang diteliti). Untuk melukiskan hal itu perhatikan gambar 2. 


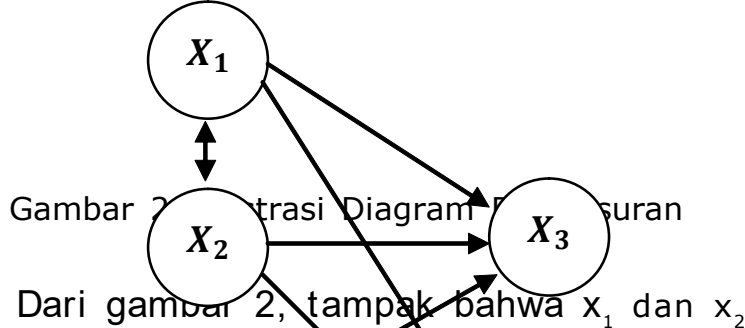
merupakan variabel-varlyel utama yang diselidiki, dan $\mathrm{x}_{3}$ dan $\times \boldsymbol{X}_{\boldsymbol{u}}$ tukan riadel-variabel utama laten (yang selidiki, hopris sintetis). Variabel-variabel utama secara $\left(\boldsymbol{X}_{\mathbf{4}}\right)$ nentukan variabel-variapor $x_{3}$ dan $x_{\text {wang }}$ diki seperti yang dinyate $\left.\boldsymbol{X}_{\boldsymbol{v}}\right)$ satu arah panah. Di sini $\mathrm{x}_{4}$ bukan hanya ra langsung bergantung pada variabel-variabel utama $\mathrm{x}_{1}$ dan $\mathrm{x}_{2}$, akan tetapi ketergantungan itu melalui variabel perantara $\mathrm{x}_{3}$. Tanda dua arah panah atau variabel $x_{1}$ dan $x_{2}$ menyatakan bahwa mereka saling memiliki ketergantungan, namun arah dari pengaruh tersebut tidak dilakukan secara eksplisit. Pada sisi lain, variabel $x_{u}$ dan $x_{v}$ merupakan dua variabel yang saling bebas (tidak ada tanda panah) dan juga bebas terhadap variabel $x_{1}$ dan $x_{2}$ (Asmin, 2002).

Analisis jalur secara khusus bertujuan untuk menyetarakan persamaan-persamaan linier yang dinyatakan sebagai sebuah fungsi dari variabelvariabel, dari mana arah panah itu bergerak (titik awal panah). Sebagai contoh dapat ditulis persamaan:

$x_{3}=b_{31} x_{1}+b_{32} x_{2}+b_{34} x_{u}$

Lihatlah ada tiga tanda panah yang berasal dari $\mathrm{x}_{1}, \mathrm{x}_{2}$ dan $\mathrm{x} 3_{\mathrm{n}}$ dan $\mathrm{x}_{\mathrm{u}}$ menuju ke $\mathrm{x}_{3}$, artinya bergantung pada $x_{1}, x_{2}$ dan $x_{4}$. Begitu pula persamaan:

$\mathrm{x}_{4}=\mathrm{b}_{41} \mathrm{x}_{1}+\mathrm{b}_{42} \mathrm{x}_{2}+\mathrm{b}_{43} \mathrm{x}_{3}+\mathrm{b}_{4 \mathrm{v}} \mathrm{x}_{\mathrm{v}}$

Dalam persamaan ini suku $b_{43} x_{3}$ dapat dieliminasi karena $x_{3}$ dapat digantikan dengan persamaan (1) sehingga diperoleh persamaan untuk $x_{4}$. Faktor-faktor utama koefisien b dalam persamaan (1) dan (2) yang dinamakan koefisien jalur. Persamaan itu sendiri dinamakan persamaan struktural.

\section{Persamaan Vektor dalam Analisis Penelusuran}

Selanjutnya kita mengasumsikan untuk bahwa variabel-variabel $x_{i}$ dinyatakan dalam bentuk baku. Ekspektasi-ekspetasi suku $x_{i}^{2}$ diartikan sebagai suku kesatuan, dan ekspektasi dari $x_{i} x_{j}$ menyatakan koefisien korelasi $r_{i j}$. Asumsi-asumsi tersebut tidak diartikan secara mendasar, tetapi secara sederhana yang merupakan perlakuan formal yang lebih besar. Tentu saja, kegunaannya untuk mengidentifikasi (mengenali) koefisienkoefisien b dalam persamaan jika korelasi-korelasi antara variabel-variabel yang diketahui. Untuk menunjukkan bagaimana hal itu dapat dilakukan, ambilah persamaan (1), dan bayangkan bahwa hal itu menyatakan sebuah persamaan vektor. Misalnya: $\mathrm{x}_{1}, \mathrm{x}_{2}$, dan $\mathrm{x}_{3}$ adalah $\mathrm{nxl}$ buah vektor dari persamaan nilai yang diselidiki (dibakukan), mengingat bahwa $\mathrm{x}_{\mathrm{u}}$ merupakan $(\mathrm{nxl})$ vektor nilai error yang tak diselidiki (juga dibakukan). Koefisien b adalah skalar pengali. Sekarang kalikan kedua sisi persamaan (1) dikalikan dengan $x_{i}^{\prime}$ sehingga diperoleh:

$x_{1} x_{3}=b_{31} x_{1} x_{1}+b_{32} x_{1} x_{2}+b_{3 u} x_{1} x_{u}$

Jika membagi persamaan ini dengan $n$ (jumlah yang diobservasi) menjadi:

$\frac{x_{i}^{\prime} x_{3}}{n}=\frac{b_{31} x_{1}^{\prime} x_{1}}{n}+\frac{b_{32} x_{1}^{\prime} x_{2}}{n}+\frac{b_{34} x_{1}^{\prime} x_{u}}{n}$

Karena secara umum berlaku:

$\frac{x_{i}^{\prime} x_{j}}{n}=r_{i j}$, dan $\frac{x_{i}^{\prime} x_{u}}{n}=0$,

Persamaan di atas menjadi:

$r_{13}=b_{31}+b_{32} r_{12}$

Di mana $r_{1 u}=0$, selama $x_{u}$ di asumsikan bebas terhadap $x_{1}$. Dengan cara yang sama mengalikan kedua suku pada persamaan (1) dengan $x_{2}$, setelah itu dibagi dengan $n$, maka hasilnya menjadi:

$\frac{x_{2}^{\prime} x_{1}}{n}=\frac{b_{31} x_{2}^{\prime} x_{1}}{n}+\frac{b_{32} x_{2}^{\prime} x_{2}}{n}+\frac{b_{34} x_{2}^{\prime} x_{u}}{n}$, atau $r_{23}=b_{31} r_{12}+b_{32}$

Persamaan (4) dan (5) merupakan dua 
persamaan yang tidak homogen dengan dua pengali $b_{31}$ dan $b_{32}$ yang tidak diketahui. Jika pengali-pengali itu dapat dicari, maka persamaan (1) dapat diketahui, kecuali untuk koefisien $b_{3 u}$. Demikian juga, jika mengalikan persamaan (1) dengan $\mathrm{x}_{\mathrm{u}}$, dibagi dengan $\mathrm{n}$ akan mendapatkan hubungan:

$\mathrm{r}_{3 \mathrm{u}}=\mathrm{b}_{3 \mathrm{u}}$

Dengan mengalikan persamaan (1) dengan $\mathrm{x}_{3}$, lalu dibagi dengan akan menghasilkan:

$\frac{x_{3}^{\prime} x_{3}}{n}=\frac{b_{31} x_{3}^{\prime} x_{1}}{n}+\frac{b_{32} x_{3}^{\prime} x_{2}}{n}+\frac{b_{34} x_{3}^{\prime} x_{u}}{n}$, atau

$1=b_{31} r_{13}+b_{32} r_{23}+b_{3 u} r_{3 u}$

Kita dapat menyelesaikan persamaan ini untuk $b_{34}$ dengan menarik kuadrat akar dari $1-b_{31}{ }^{-}$ $\mathrm{b}_{32} \mathrm{r}_{23}$, dengan demikian persamaan (1) telah lengkap. Dengan cara yang sama kita dapat menyelesaikan persamaan (2).

\section{Saling ketergantungan variabel dalam Analisis Penelusuran}

Untuk menjelaskan pendekatan umum dalam analisis penelusuran ini, sebuah contoh akan diberikan, di mana terdapat empat buah variabel. Dalam hal ini diasumsikan bahwa indeks variabel menyatakan urutan waktu. Jika $i<j$ variabel $i$ dapat menjadi sebuah penentu terhadap variabel $j$, namun variabel $j$ tidak dapat menjadi penentu bagi variabel i. Hal ini menuntun kita untuk menentukan model recursive yang akan dijelaskan melalui gambar 3. Dari gambar tersebut, hubungan antar variabel adalah sebagai berikut.

$\mathrm{x}_{1}$ penentu bagi $\mathrm{x}_{1}, \mathrm{x}_{2}$ dan $\mathrm{x}_{3}$

$x_{2}$ ditentukan oleh $x_{1}$, sementara $x_{2}$ penentu terhadap $x_{4}$ dan $x_{4}$

$x_{3}$ ditentukan oleh $x_{1}$ dan $x_{2}$, sementara $x_{3}$ penentu terhadap $x_{4}$ $\mathrm{x}_{4}$ ditentukan oleh $\mathrm{x}_{1}, \mathrm{x}_{2}$ dan $\mathrm{x}_{3}$

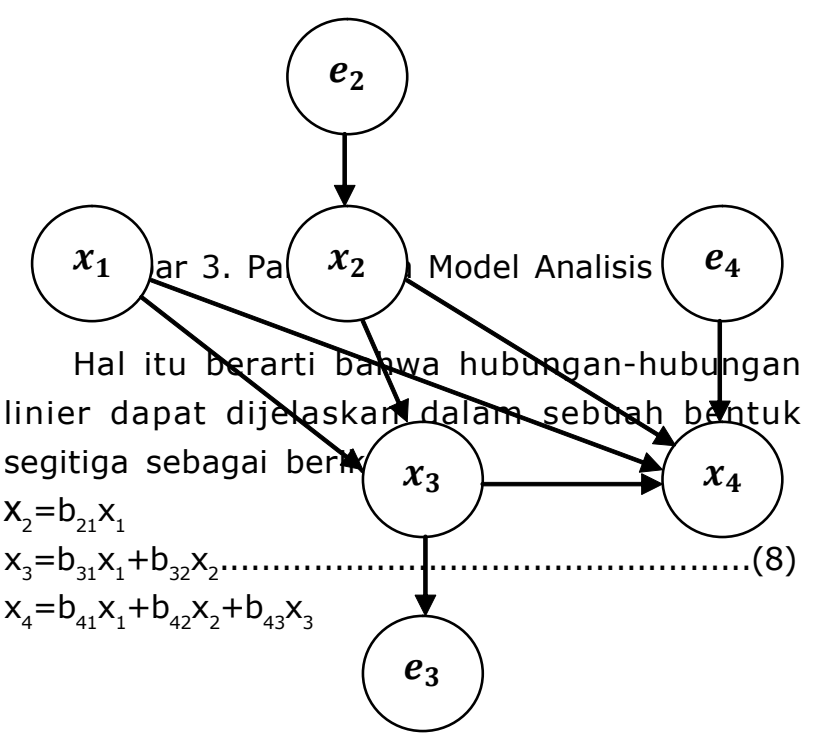

Model ini secara nyata cukup sulit, secara tidak langsung cukup kompleks untuk menentukan semua variabel dengan $x_{1}$. Meskipun kita menambahkan variabel-variabel yang tidak terobservasi dalam persamaan, akan tetapi $e_{i}$ merupakan komponen $x_{i}$ sehingga bebas terhadap variabel-variabel $x$ terdahulu (dalam hal ini $e_{i}$ dapat menjadi sebuah variabel random error, atau sebuah komponen khusus sistematik dari $x_{i}$ atau keduanya). Selanjutnya komponen-komponen itu menjadi:

$x_{2}=b_{21} x_{1}+b_{2 e} e_{2}$

$x_{3}=b_{31} x_{1}+b_{32} x_{2} b_{3} e_{3}$

$x_{4}=b_{41} x_{1}+b_{42} x_{2}+b_{43} x_{3}+b_{4 e} e_{4}$

Di sini $e_{2}$ merupakan sebuah variabel yang dipostulatkan untuk menjelaskan varians dalam $x_{2}$ yang tidak ditentukan oleh $x_{1}$, sehingga $x_{2}$ bergantung sebagian pada $\mathrm{x}_{1}$ dan sebagian pada komponen khusus $e_{2}$. Secara umum, kita mengasumsikan bahwa variabel laten $e_{1}$ adalah bebas terhadap semua variabel $\mathrm{x}_{\mathrm{h}},(\mathrm{h}<\mathrm{i})$ yang terdahulu, dan kita mengasumsikan juga bahwa semua variabel-variabel e yang tidak dikorelasi- 
kan. Suatu variabel $e_{i}$ dinamakan sebagai komponen exogenous, yang berarti menjadi sebuah sumber variasi yang tidak bergantung pada variabel-variabel lain dalam sistem tersebut. Dalam hal ini, analisis penelusuran seperti yang telah dijelaskan sebelumnya merupakan faktorfaktor utama dari e; bersama dengan $\mathrm{x}_{1}$; di mana $x_{1}$ itu sendiri juga merupakan variabel exogenous.

Kumpulan persamaan-persamaan (9) secara tidak langsung mengatakan bahwa $x_{2}, x_{3}$ dan $x_{4}$ bukan merupakan faktor-faktor utama tetapi merupakan variabel terikat atau variabel endogenous yang dapat dilihat jika misalnya, mengeliminasi $x_{2}$. Artinya mensubstitusikan $x_{2}$ ke ruas kanan persamaan pertama, lalu variabel $x_{3}$ menjadi bergantung kepada $\mathrm{x}_{1}, \mathrm{e}_{2}$ dan $\mathrm{e}_{3}$. Dengan cara yang sama pada persamaan ketiga, mengeleminasi $x_{3}$, kemudian mengeleminasi $x_{2}$, sehingga $x_{4}$ menjadi fungsi linier dari $x_{1}, e_{2}$ dan $e_{3}$ dan $e_{4}$.

Sekarang semua persamaan (9) merupakan persamaan-persamaan vektor. Misalnya $x$ merupakan vektor-vektor kolom dari $\mathrm{n}$ buah nilai yang diobservasi, dan e adalah vektor-vektor kolom dari $\mathrm{n}$ buah nilai yang tidak diobservasi. Aturan untuk menemukan pemecahan terhadap b adalah dengan cara mengambil satu dari persamaan yang mengandung $x_{1}$ (untuk membuat aturan umum), kalikan kedua ruas dengan $x_{g}^{\prime}$ untuk semua nilai dari $\mathrm{g}<\mathrm{i}$. Kemudian bagilah kedua ruas dengan $n$, dan hasilnya adalah persamaan-persamaan itu berbentuk:

$r_{i g}=b_{i 1} r_{1 g}+b_{i 2} r_{2 g}+\ldots+b_{i, i}-1 r_{i-1, g}$

Dengan asumsi semua korelasi-korelasi $r_{g, e i}$ adalah nol.

Untuk melukiskan aturan itu, maka ambillah persamaan dari (9), kemudian kalikan kedua sisi dengan $x_{1}^{\prime}$, dan setelah itu bagilah dengan $n$, sehingga:

$$
\frac{x_{1}^{\prime} x_{2}^{\prime}}{n}=\frac{b_{21} x_{1}^{\prime} x_{2}}{n}, \quad \text { atau } r_{12}=b_{21}
$$

Ini merupakan pemecahan-pemecahan untuk $\mathrm{b}_{21}$. Selanjutnya ambillah persamaan kedua yang mengandung $x_{3}$. Pertama, kalikan kedua sisi dengan $x_{1}^{\prime}$ dan setelah itu bagilah dengan $n$, sehingga:

$$
\begin{aligned}
& \frac{x_{1}^{\prime} x_{3}^{\prime}}{n}=\frac{b_{31} x_{1}^{\prime} x_{2}}{n}+\frac{b_{32} x_{1}^{\prime} x_{2}}{n}+\frac{b_{3 e} x_{1}^{\prime} e_{3}}{n} \text {, atau } \\
& r_{13}=b_{31}+b_{32} r_{12}
\end{aligned}
$$

Kemudian kalikan lagi kedua ruas dengan $x_{2}^{\prime}$, dan setelah itu bagilah dengan $n$, sehingga:

$\frac{x_{2}^{\prime} x_{3}^{\prime}}{n}=\frac{b_{31} x_{2}^{\prime} x_{2}}{n}+\frac{b_{32} x_{2}^{\prime} x_{2}}{n}+\frac{b_{3 e} x_{2}^{\prime} e_{3}}{n}$, atau

$r_{23}=b_{31} r_{12}+b_{32}$

Kedua hasil persamaan-persamaan (11a) dan (11b) merupakan dua persamaan yang tidak homogen di mana keduanya tidak diketahui, tetapi dapat dipecahkan untuk b. Lakukanlah hal yang sama pada persamaan (9) yang mengandung $x_{4}$ dengan mengalikan lagi kedua ruas dengan $x_{1}^{\prime}$, dan setelah itu bagilah dengan $n$, sehingga:

$\frac{x_{1}^{\prime} x_{4}^{\prime}}{n}=\frac{b_{41} x_{1}^{\prime} x_{1}}{n}+\frac{b_{42} x_{1}^{\prime} x_{2}}{n}+\frac{b_{43} x_{1}^{\prime} x_{3}}{n}+\frac{b_{4 e} x_{1}^{\prime} x_{4}}{n}$

atau

$r_{24}=b_{41} r_{12}+b_{42}+b_{43} r_{23}$

Kemudian kalikan lagi kedua ruas dengan $x_{3}^{\prime}$, dan setelah itu bagilah dengan $n$, sehingga:

$\frac{x_{3}^{\prime} x_{4}}{n}=\frac{b_{41} x_{3}^{\prime} x_{1}}{n}+\frac{b_{42} x_{3}^{\prime} x_{2}}{n}+\frac{b_{43} x_{3}^{\prime} x_{3}}{n}+\frac{b_{4 e} x_{2}^{\prime} e_{4}}{n}$

atau

$r_{34}=b_{41} r_{13}+b_{42} r_{23}+b_{43}$

Penulis telah mendapatkan tiga persamaan yang tak homogen dan ketiganya tidak diketahui, dan dapat dipecahkan untuk b. Secara umum, untuk ke i buah persamaan, aturan hasil dalam $i$ persamaan-persamaan yang tidak homogen dalam i persamaan yang tidak diketahui, namun kita dapat menyelesaikannya untuk mencari nilainilai $b_{i}$. Selanjutnya perlu diketahui bahwa determinasi dari koefisien-koefisien tidak sama dengan nol. Determinasi tersebut merupakan determinasi $\left|R_{i}-1\right|$, di mana $R_{i-1}$ merupakan matriks antara korelasi-korelasi pertama dari (i-1) variabel-variabel yang diobservasi.

Secara umum, keinginan tersebut akan ditemukan juga. Jika tidak ditemukan, berarti kita dapat menemukan suatu variabel yang 
diobservasi dalam kelompok tersebut (lebih dari satu) yang secara utuh bergantung pada yang lainnya. Variabel ini dapat berlebih jumlahnya, sehingga perlu dihilangkan, tetapi tanpa menghilangkan informasinya. Peristiwa ini agaknya tidak seperti yang diaplikasikan dalam kerja. Terakhir, untuk mencari koefisien $b_{i e}$ kedua ruas dikalikan dengan $e_{1}^{\prime}$, sehingga diperoleh: $r_{i_{i}}=b_{i, e}$, sehingga tampak bahwa $b_{i . e}$ selalu sama dengan korelasi antara sebuah variabel dan komponen e yang dimiliki itu. Yang kedua, kalikan persamaan dengan $x_{i}^{\prime}$, sehingga diperoleh persamaan sebagai berikut:

$1+b_{i 1} r_{1 i}+b_{i 2} r_{21}+\ldots+b_{i, i-1} r_{i, i-1}+b_{i e} r_{i, e}$

\section{Aplikasi Path Analysis di Bidang Pendidikan}

Analisis jalur (path analysis) memungkinkan untuk mengakses perluasan sejauh mana data yang berhasil dikumpulkan konsisten dengan a hypothesized causal structure. Sebenarnya tidak membentuk hubungan kausal sebenarnya (true causal relationship), karena tidak ada temporal ordering among the variables that compose the causal sequence (Supranto, 2004). Di sini dikemukakan sebuah contoh konkrit yang diadopsi dan dimodifikasi dari hasil penelitian Blau dan Duncan dalam Asmin (2002), yang melibatkan lima buah variabel yang menjelaskan tentang proses sertifikasi pekerjaan orang tua dan anak sebagai berikut.

$\mathrm{x}_{1}=$ tingkat pendidikan orang tua

$\mathrm{x}_{2}=$ status pekerjaan ayah

$\mathrm{x}_{3}=$ tingkat pendidikan anak

$\mathrm{x}_{4}$ =tingkat pekerjaan dari pekerjaan anak pertama

$\mathrm{x}_{5}$ =tingkat pekerjaan dari pekerjaan anak kedua Dari studi yang dilakukan maka diperoleh hubungan antar variabel seperti terlihat pada Tabel 1.
Diagram path analysis dari variabel itu digambarkan sebagai berikut.

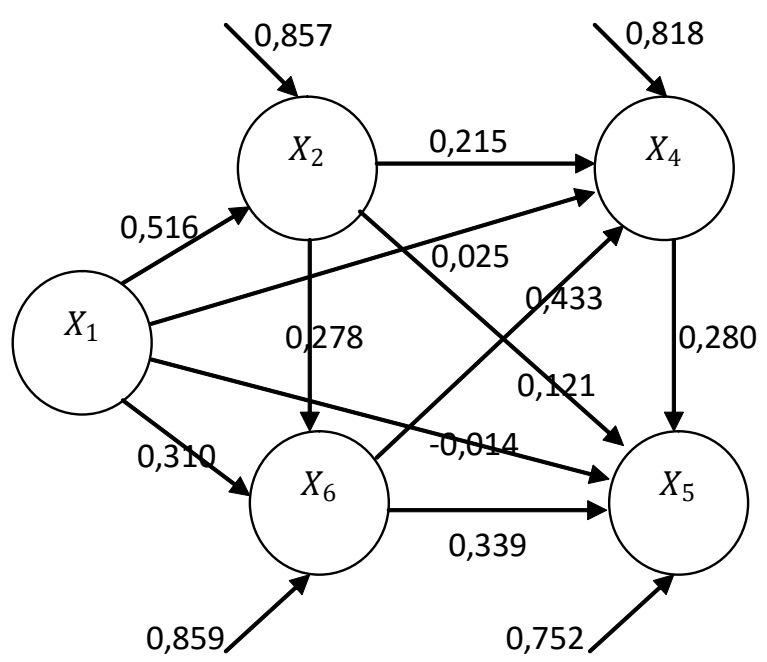

Penerapan prosedur yang telah dijelaskan di atas dapat menghasilkan struktur persamaan berikut.

$x_{2}=0,516 x_{1}+0,857 e_{2}$ $x_{3}=0,310 x_{1}+0,278 x_{2}+0,859 e_{3}$ $x_{4}=0,025 x_{1}+0,215 x_{2}+0,433 x_{3}+0,818 e_{4}$ $x_{5}=0,014 x_{1}+0,121 x_{2}+0,399 x_{3}+0,280 x_{4}+$ $0,280 \mathrm{x}_{4}+0,752 \mathrm{e}_{5}$

Contoh lain adalah penelitian yang telah dilakukan oleh Agung dan Subroto (2010), yang melibatkan empat buah variabel dengan model teoritik penelitian digambarkan sebagai berikut.

Hipotesis dalam studi ini sebagai berikut: (1) terdapat pengaruh budaya organisasi $\left(X_{1}\right)$ terhadap kepuasan kerja $\left(\mathrm{X}_{3}\right)$ (2) terdapat pengaruh kepemimpinan $\left(X_{2}\right)$ terhadap kepuasan kerja $\left(\mathrm{X}_{3}\right),(3)$ terdapat pengaruh budaya organisasi $\left(X_{1}\right)$ terhadap kinerja $\left(X_{4}\right),(4)$ terdapat pengaruh kepemimpinan $\left(X_{1}\right)$ terhadap kinerja $\left(X_{4}\right)$, dan (5) terdapat pengaruh kepuasan kerja $\left(X_{3}\right)$ terhadap kinerja $\left(\mathrm{X}_{4}\right)$. Di dalam menghitung

Tabel 1. Matriks Interkorelasi antar Variabel

\begin{tabular}{|c|c|c|c|c|c|}
\hline $\mathbf{r}$ & $\mathrm{x}_{1}$ & $\mathrm{x}_{2}$ & $\mathrm{x}_{3}$ & $\mathrm{x}_{4}$ & $\mathrm{x}_{5}$ \\
\hline $\mathrm{x}_{1}$ & 1,000 & 0,516 & 0,453 & 0,332 & 0,322 \\
\hline $\mathrm{x}_{2}$ & & 1,000 & 0,438 & 0,417 & 0,405 \\
\hline $\mathrm{x}_{3}$ & & & 1,000 & 0,538 & 0,596 \\
\hline $\mathrm{x}_{4}$ & & & & 1,000 & 0,541 \\
\hline $\mathrm{x}_{5}$ & & & & & 1,000 \\
\hline
\end{tabular}




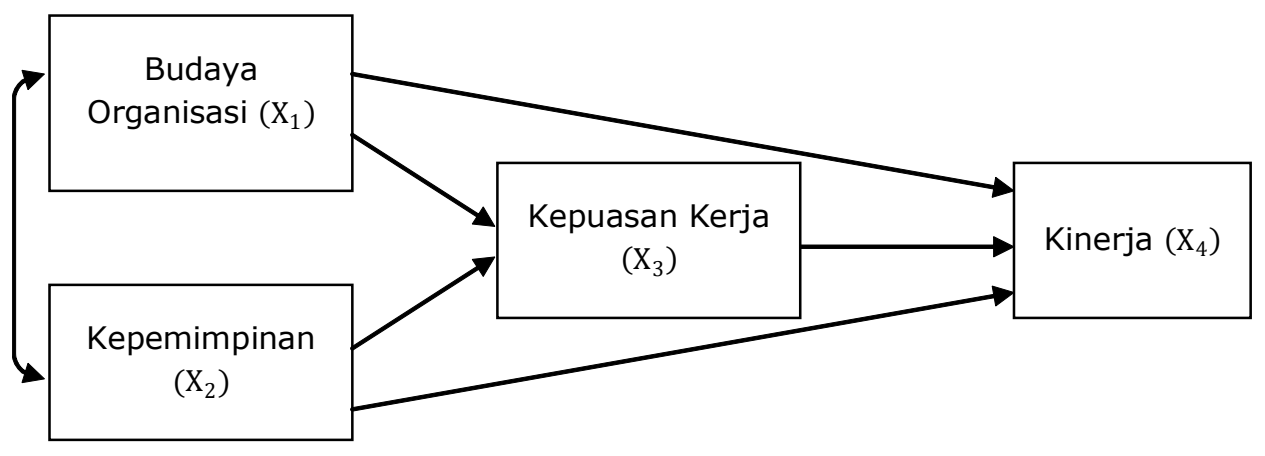

besaran pengaruh, dibagi ke dalam 2 (dua) persamaan struktur, yakni:

Persamaan Struktur 1:

$\mathrm{X}_{3}=\mathrm{Px}_{3} \mathrm{X}_{1}+\mathrm{Px}_{3} \mathrm{X}_{2} \mathrm{X}_{2}+\stackrel{\circ}{\mathrm{a}}_{1}$

Pada output Model Summary diketahui $R^{2}=0,718^{2}=0,515$. Sehingga diperoleh Koefisien Residu $=1-0,516=0,485$.

Persamaan struktur 1 ditulis: $X_{3}=0,254^{*} X_{1}+0,592^{*} X_{2}+0,485$

Diagram Jalur Struktur $\mathrm{X}_{1}$ dan $\mathrm{X}_{2}$ terhadap $\mathrm{X}_{3}$

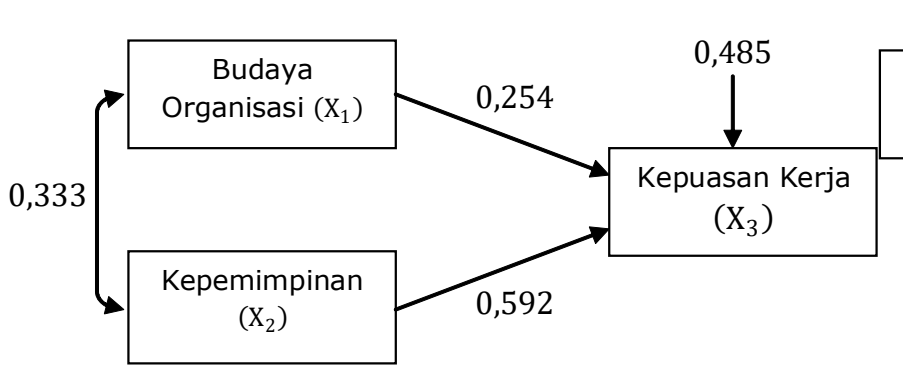

Persamaan Struktur 2:

$\mathrm{X}_{4}=\mathrm{Px}_{4} \mathrm{X}_{1} \mathrm{X}_{1}+\mathrm{Px}_{4} \mathrm{X}_{2} \mathrm{X}_{2}+\mathrm{Px}_{4} \mathrm{X}_{3} \mathrm{X}_{3}+\varepsilon_{2}$

Pada output Model Summary diketahui $\mathrm{R}^{2}=0,830^{2}=0,689$, sehingga diperoleh Koefisien Residu $=1-0,689=0,311$.

Persamaan struktur 2 ditulis:

$X_{4}=0,148 * X_{1}+0,265 * X_{2}+0,548 * X_{3}+0,311$

Diagram Jalur Struktur $\mathrm{X}_{1}, \mathrm{X}_{2}, \mathrm{X}_{3}$ terhadap $\mathrm{X}_{4}$ :

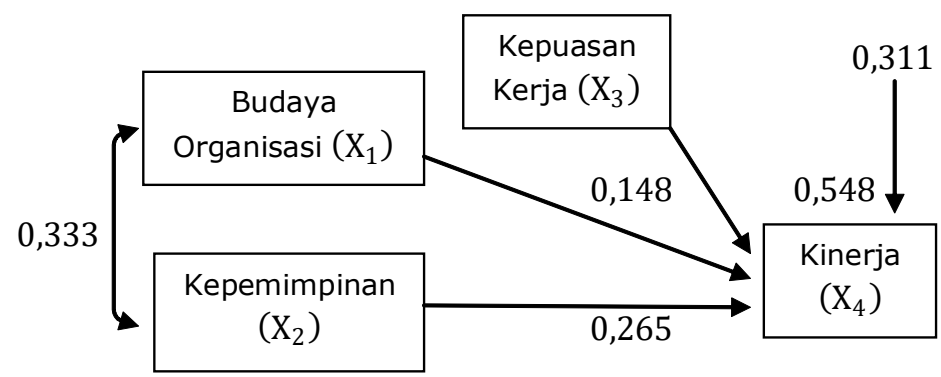

Penelitian dengan metode survei menggunakan analisis jalur (Kustoro, 2010), dimana hubungan kausal dilakukan untuk menguji pengaruh langsung maupun tidak langsung Kekohesifan, Gaya Kepemimpinan, Budaya Kerja terhadap efektivitas organisasi Perusahaan Pengadaan Alat-alat Teknis Pendidikan di Jakarta. Model analisis yang akan digali dalam penelitian ini dapat digambarkan sebagai berikut.

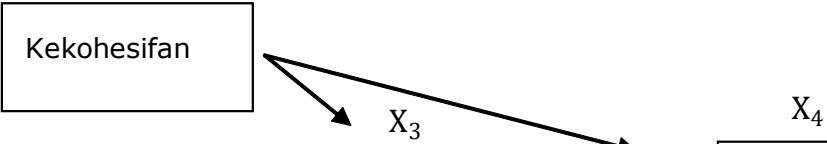

Gaya Kepemimpinan

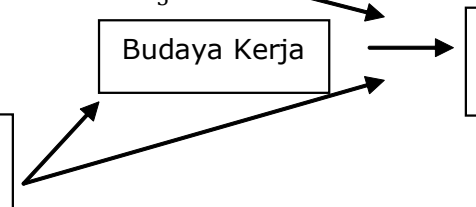

Efektivitas organisasi
Hasil penelitian ini menemukan bahwa: Pertama, pengaruh langsung kekohesifan terhadap budaya kerja ditunjukkan melalui koefisien jalur $\left(\rho_{31}\right)=0,350$ dan terbukti sangat signifikan. Temuan menegaskan bahwa kekohesifan $\left(\mathrm{X}_{1}\right)$ berpengaruh langsung terhadap budaya kerja $\left(\mathrm{X}_{3}\right)$. Kedua, pengaruh langsung gaya kepemimpinan terhadap budaya kerja ditunjukkan melalui harga koefisien jalur $\left(\rho_{32}\right)=0,498$ dan terbukti sangat signifikan. Temuan menegaskan bahwa gaya kepemimpinan $\left(\mathrm{X}_{2}\right)$ berpengaruh langsung terhadap budaya kerja $\mathrm{X}_{3}$. Dengan kata lain makin kuat gaya kepemimpinan, makin tinggi budaya kerja. Ketiga, pengaruh langsung kekohesifan terhadap efektivitas organisasi diketahui melalui harga koefisien jalur $\left(\rho_{41}\right)=0,365$ dan terbukti sangat signifikan. Temuan menegaskan bahwa kekohesifan $\left(X_{1}\right)$ berpengaruh langsung terhadap efektivitas organisasi $\left(X_{4}\right)$. Dengan kata lain, makin tinggi kekohesifan, makin tinggi efektivitas organisasi. 
Keempat, pengaruh langsung gaya kepemimpinan terhadap efektivitas organisasi ditunjukkan melalui harga koefisien jalur $\left(\rho_{42}\right)=0,268$ yang terbukti sangat signifikan. Temuan menegaskan bahwa gaya kepemimpinan $\left(\mathrm{X}_{2}\right)$ berpengaruh langsung terhadap efektivitas organisasi $\left(\mathrm{X}_{4}\right)$. Dengan kata lain, makin tinggi gaya kepemimpinan, makin tinggi efektivitas organisasi. Kelima, pengaruh langsung budaya kerja terhadap efektivitas organisasi ditunjukkan melalui harga koefisien jalur $\left(\rho_{43}\right)=0,341$ yang terbukti sangat signifikan. Temuan menegaskan bahwa budaya kerja $\left(\mathrm{X}_{3}\right)$ berpengaruh langsung terhadap efektivitas organisasi $\left(\mathrm{X}_{4}\right)$. Dengan kata lain, makin tinggi budaya kerja, makin tinggi efektivitas organisasi. Keenam, pengaruh tidak langsung kekohesifan terhadap efektivitas organisasi melalui budaya kerja $r 31 \times r 43=$ $0,35 \times 0,341=0,119$ yang terbukti sangat signifikan. Dengan kata lain, makin tinggi kekohesifan makin tinggi efektivitas organisasi melalui budaya kerja.

Untuk mendapatkan hasil yang wajar dalam pengujian model penelitiannya, secara sederhana peneliti dapat mengikuti enam langkah yang sering dianjurkan oleh para penyusun buku tuntutan metodologi (Tacg, 1997), antara lain: (a) membangun model atau skema kausal, (b) membangun pola hubungan antar variabel dalam suatu urutan, (c) menggambarkan diagram path, (d) menghitung path coefficients untuk model dasarnya, (e) menguji goodness of fit dengan model dasar itu, dan (f) membuat interpretasi terhadap hasilnya. Dengan melihat contoh-contoh penelitian menggunakan model analisis jalur tersebut, maka perlu dikembangkan variabel-

Temuan peneliti ini dapat dirangkum sebagai berikut.

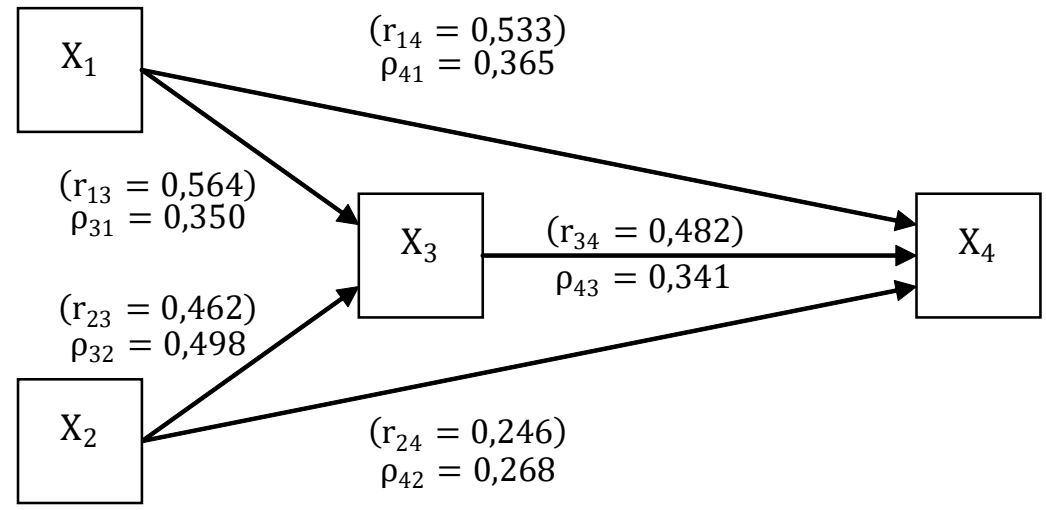

variabel lain yang masih sangat banyak jika dianalisis dengan model ini.

\section{Simpulan dan Saran Simpulan}

Metode path analysis adalah suatu metode yang mengkaji pengaruh (efek) langsung maupun tidak langsung dari variabel-variabel yang dihipotesiskan sebagai akibat pengaruh perlakuan terhadap variabel tersebut. Tujuan analisis jalur adalah menerangkan akibat langsung dan tidak langsung seperangkat variabel, sebagai variabel penyebab, terhadap variabel lainnya yang merupakan variabel akibat. Hasil penelusuran literatur dan contoh-contoh penelitian yang menggunakan analisis jalur menunjukkan bahwa analisis jalur sangat efektif dan perlu dikembangkan dalam penelitian pendidikan. Dalam model kausal, harus dibedakan antara variabel eksogen dan endogen. Variabel eksogen adalah variabel yang variabilitasnya diasumsikan ditentukan oleh sebab-sebab yang berada di luar model. Sedangkan variabel endogen adalah variabel yang variasinya dapat diterangkan oleh variabel eksogen dan endogen yang berada di dalam sistem.

\section{Saran}

Bagi peneliti pemula pemakaian dan pemanfaatan metode path analysis ini dapat saja dilakukan walaupun ada beberapa kesulitan yang akan ditemukan dalam proses pengurutan dan penempatan variabel. Namun demikian, metode ini merupakan salah satu metode alternatif yang digunakan dalam menganalisis hasil penelitian, selama masalah dan disain penelitian itu memang menunjang pemakaian metode analisis ini. dengan demikian path analysis (analisis jalur) ini 
dapat menjadi salah satu alternatif analisis yang mendorong para peneliti untuk meningkatkan kreativitas meneliti terutama untuk memotivasi dan membangkitkan semangat dalam peningkatan kualitas penelitiannya, paling tidak untuk konsumsi bagi penelitian di masing-masing di lembaga tempat peneliti berbeda. Kiranya analisis jalur ini dapat lebih dikembangkan untuk tujuan yang bermanfaat bagi pengembangan ilmu, terutama pengembangan Penelitian dan Evaluasi Pendidikan.

\section{Pustaka Acuan}

Agung, Iskandar, dan Gatot Subroto. 2010. "Peran Faktor Non-Ekonomis dalam Penyelenggaraan Pendidikan". Jurnal Pendidikan dan Kebudayaan, Volume 16. Nomor. 2. Maret 2010.

Asmin, 2002. "Penerapan Path Analysis Menurut Penempatan Urutan Variabel dalam Penelitian, Presisi: Jurnal Penelitian dan Evaluasi Pendidikan,Vol.1. no. 2. Maret 2002, Jakarta: Program Studi PEP UNJ.

Abdurahman, Maman, Sambas Ali Muhidin, dan Ating Somantri. 2011. Dasar-Dasar Metode Statistika untuk Penelitian, Bandung: Pustaka Setia.

Goldstein, D. F. 1985. Multivariat Statistics Methods, Tokyo: McGraw Hill Kogakusha Ltd.

Hasan, Zaini, 2002. Pengantar Analisis Hubungan Kausal (Analisis Jalur), Malang: Pusat Penelitian IKIP Malang.

Jacques Tacg, 1997. Multivariate Analysis Techniques in Social Science Research From Problem to Analysis, London: Sage Publication.

Kerlinger, Fred. N. 2003. Asas-asas Penelitian Behavioral. Terj. Landung R Simatupang, Yogyakarta: Gadjah Mada University Press.

Kusnendi, 2005. Analisis Jalur: Konsep dan Aplikasi Dengan Program SPSS \& LISREL 8, Bandung: Badan Penerbit Pendidikan Ekonomi UPI.

Kustoro, Bambang D. 2010. "Pengaruh Gaya Kepemimpinan dan Budaya Kerja Terhadap Efektivitas Organisasi". Jurnal Pendidikan dan Kebudayaan. Vol. 16. No. 3, Mei 2010.

Maruyama, Geofrey M. 1998. Basic of Structural Equation Modeling, New Jersey: Sage Publication, Inc.

Muhidin, Sambas A, dan Maman Abdurahman. 2009. Analisis Korelasi, Regresi, dan Jalur dalam Penelitian, Bandung: Pustaka Setia.

Pedhazur. J. Elazar, 1982. Multiple Regression in Behavioral Research. New York: Hott. Rinehart and Winston.

Riduwan, Kuncoro. E.A, 2007. Cara Menggunakan dan Memaknai Analisis Jalur (Path Analysis), Bandung: Alfabeta.

Sri Sularso, 2003. Buku Pelengkap Metode Penelitian Akuntansi: Suatu Pendekatan Replikasi, Yogyakarta: BPFE.

Sugiyono, 2006. Metode Penelitian Kuantitatif Kualitatif dan Penelitian Pengembangan, Bandung: Alfabeta.

Supranto, J. 2004. Analisis Multivariat: Arti dan Interpretasi, Jakarta: Rineka Cipta.

Winarsunu, T, 2003. Statistik Dalam Penelitian Psikologi dan Pendidikan, Malang: Universitas Muhammadiyah Malang. 